\title{
Coexistence of Pulmonary Tuberculosis and Sarcoidosis
}

\author{
Pulmoner Tüberküloz ve Sarkoidoz Birlikteliği \\ Serap Argun Barış', Adnan Batman², Salih Küçük' , Sevtap Gümüştaş ${ }^{3}$
}

\section{Abstract}

Tuberculosis (TB) and sarcoidosis are granulomatous diseases with different etiologies and management; however, they have similar clinical and histological characteristics. Coexistence of TB and sarcoidosis is extremely rare. Presently described is a case of coexistence of pulmonary tuberculosis and sarcoidosis confirmed microbiologically and histopathologically.

Key words: Sarcoidosis, tuberculosis, coexistence, diagnosis.

\section{Özet}

Sarkoidoz ve tüberküloz farklı etyoloji ve tedaviye sahip ancak klinik ve histolojik olarak birbiri ile sıkça karışan hastalıklardır. Tüberküloz ve sarkoidoz birlikteliği nadirdir. Burada mikrobiyolojik ve histopatolojik olarak kanıtlanmış tüberküloz ve sarkoidoz birlikteliği olan olgu sunulmaktadır.

Anahtar Sözcükler: Sarkoidoz, tüberküloz, birliktelik, tanı.
Tuberculosis (TB) and sarcoidosis are granulomatous diseases with different etiologies and management; however, they have similar clinical and histological characteristics (1). Distinguishing sarcoidosis from pulmonary TB can sometimes be a great challenge to physicians, especially in developing countries where there is high prevalence of TB (2). Coexistence of these 2 diseases is extremely rare (3-5). Case of coexistence of TB and sarcoidosis is described in this report.
'Department of Pulmonary Diseases, Kocaeli University Faculty of Medicine, Kocaeli, Turkey

${ }^{2}$ Department of Internal Medicine, Mus Government Hospital, Mus, Turkey

${ }^{3}$ Department of Radiology, Kocaeli University Faculty of Medicine, Kocaeli, Turkey
'Kocaeli Üniversitesi Tıp Fakültesi, Göğüs Hastalıkları Anabilim Dalı, Kocaeli

${ }^{2}$ Muş Devlet Hastanesi, İç Hastalıkları Bölümü, Muş

${ }^{3}$ Kocaeli Üniversitesi Tıp Fakültesi, Radyoloji Anabilim Dalı, Kocaeli

Submitted (Başvuru tarihi): 29.12.2016 Accepted (Kabul tarihi): 13.02.2017

Correspondence (iletişim): Serap Argun Barış, Department of Pulmonary Diseases, Kocaeli University Faculty of Medicine, Kocaeli, Turkey

e-mail: serapargun2002@yahoo.com 


\section{CASE}

A 50-year-old woman presented at outpatient clinic with fatigue, nonproductive cough and backache of 2-month duration. She had no history of smoking or medication. There was no history of contact with TB and vital signs were normal. Crackles at base of both lungs were heard on physical examination. There was bilateral hilar enlargement, increased interstitial and reticulonodular opacity on chest $X$-ray (Figure 1). Thorax CT revealed bilateral enlargement of mediastinal lymph nodes, septal thickening, and parenchymal perilymphatic nodules (Figures $2 a$ and $b)$.

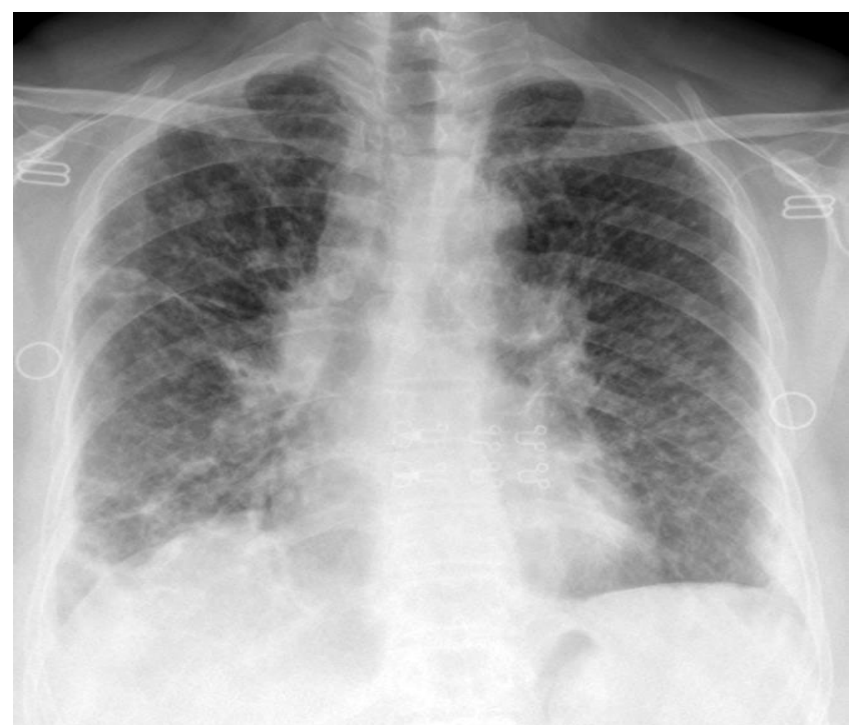

Figure 1: Initial chest $X$-ray revealed bilateral hilar enlargement, and increased interstitial and reticulonodular opacities
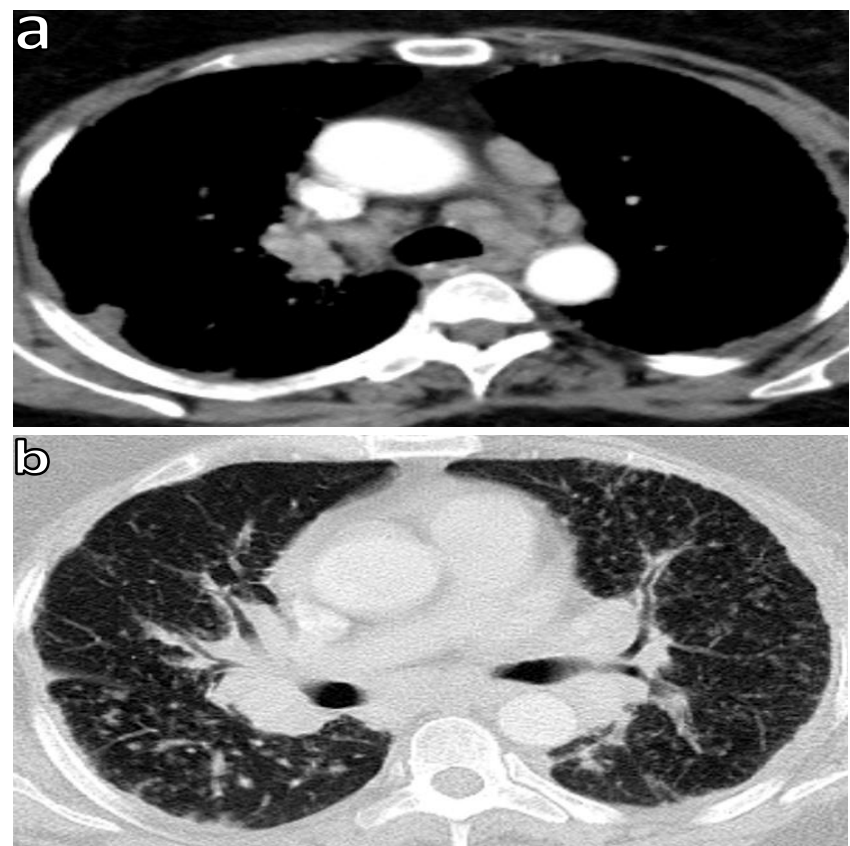

Figure $2 a$ and $b$ : Initial thorax computed tomography findings were enlarged bilateral hilar and mediastinal lymph nodes, septal thickening, and parenchymal perilymphatic nodules
There were no laboratory abnormalities except increased level of angiotensin converting enzyme (ACE), C-reactive protein (CRP) and increased sedimentation rate [ACE: 110 (normal range: 0-52 U/L), sedimentation rate: 48/h, CRP: $2.5 \mathrm{mg} / \mathrm{dL}$ (normal range: $0-0.5 \mathrm{mg} / \mathrm{dL}$ )]. Tuberculin skin test anergy was noted, though she had bacillus Calmette-Guérin scar. Carbon monoxide diffusion test was $44 \%$ of predictive value. Fiberoptic bronchoscopy revealed enlarged right secondary carina. Bronchoalveolar lavage, bronchial washing, and bronchial mucosal biopsy were performed during bronchoscopy. Fine needle aspiration of subcarinal lymph node was nondiagnostic. Gram and acid-fast bacilli (AFB) staining of bronchial lavage material was negative. There was lymphocytic alveolitis and CD4/CD8 ratio was 4.5. Pathological evaluation of mucosal biopsy from right secondary carina revealed granulomatous inflammation. Immunohistochemical evaluation of biopsy specimen revealed immunoreactivity with CD68 in epithelial histiocytes (Figures 3 $A$ and $B$ ). Histopathological findings of lung biopsy were consistent with sarcoidosis. The patient was diagnosed with stage 2 sarcoidosis. Consultation was arranged with departments of internal disease, cardiology, and ophthalmology. There was no involvement of the eye, skin, or heart. As clinical condition was stable, corticosteroid treatment was not initiated. Follow-up of clinical and radiological progress was planned; however, Lowenstein Jensen medium culture of bronchial lavage was positive on 25th day. She was diagnosed with TB and treated with rifampicin $600 \mathrm{mg}$, isoniazid $300 \mathrm{mg}$, ethambutol 1500 mg, and pyrazinamide $2000 \mathrm{mg}$ on a daily basis for 2 months, after which pyrazinamide and ethambutol were excluded, and dual therapy was continued for 4 months. The patient was in good clinical condition and there was radiological improvement of parenchymal nodules, though no change in lymph nodes or interstitial opacities after anti-TB treatment (Figure 4). Clinical and microbiological assessments were evaluated as TB coexisting with sarcoidosis.

\section{DISCUSSION}

TB and sarcoidosis are chronic granulomatous diseases with similar clinical and histopathological characteristics. Differential diagnosis of sarcoidosis and TB is a great challenge to clinicians, particularly in countries with high prevalence of TB (6). TB is infectious disease caused by Mycobacterium tuberculosis and it is still a major health problem worldwide. It is characterized by caseating granuloma and treatment is focused on elimination of micro- 
organism (7). It is often difficult to diagnose, especially when caseous necrosis is not seen and AFB staining is negative in specimens of TB patients (8). Sarcoidosis is a multisystem disease of unknown etiology, characterized by presence of non-caseating granuloma in the lungs, lymph nodes, and other organs (6).

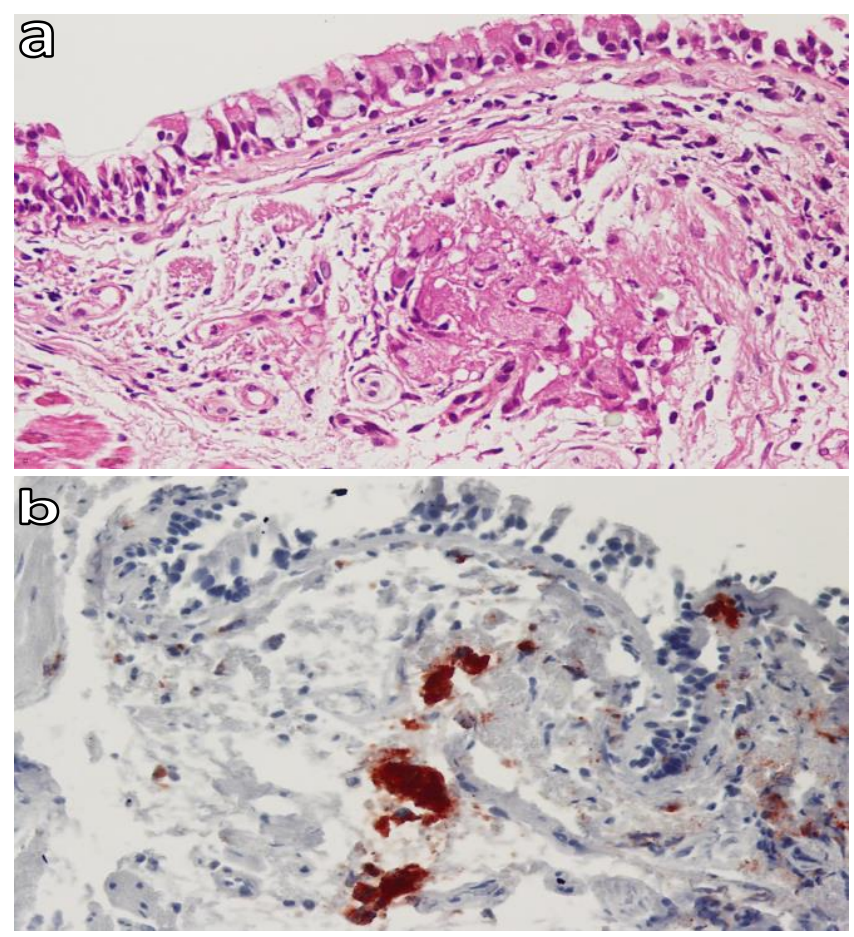

Figure $3 a$ and b: (a) Epithelial histiocyte group under surface epithelium (H\&E x400); (b) Immunoreactivity with CD68 in epithelial histiocytes $(\mathrm{CD} 68 \times 400)$

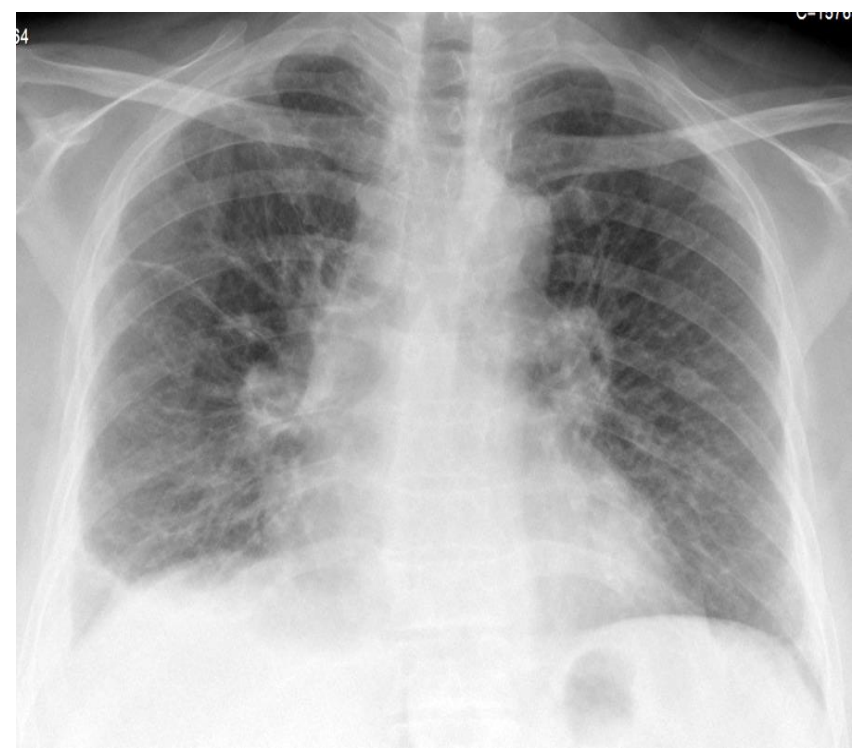

Figure 4: Follow-up chest $X$-ray after antituberculosis treatment revealed radiological improvement of parenchymal nodules but no change in lymph nodes or interstitial opacities
The role of mycobacterium as etiological agent in development of sarcoidosis has been investigated in the literature due to clinical and histological similarities of these diseases $(8,9)$. Current approaches indicate increased prevalence of sarcoidosis in TB-endemic regions (8). In a meta-analysis, it was suggested that there is association between mycobacterium (both Mycobacterium tuberculosis complex and nontuberculous) and sarcoidosis (9). Sarcoidosis occasionally develops in patients previously treated for tuberculosis $(3,6,10)$. Less commonly, TB develops as an opportunistic infection in patients following corticosteroid treatment for sarcoidosis (5). Coexistence of TB and sarcoidosis is rare (2-5).

Clinical and radiological features of TB and sarcoidosis overlap quite a bit and therefore, diagnostic dilemma often persists. Clinical presentation of sarcoidosis is generally nonspecific. Constitutional symptoms such as fever, fatigue, and weight loss are present in approximately one-third of patients, similar to our patient. Chest X-ray usually shows hilar and mediastinal enlargement. Interstitial or nodular opacities suggesting interstitial lung disease may also be seen. High resolution CT of thorax shows thickening of the interlobular septa and peribronchovascular bundles and perilymphatic nodules (2). Clinical and radiological findings of this case were consistent with the literature.

Diagnosis is established most securely when clinical and radiological findings are supported by histological evidence (2). In this case, diagnosis of sarcoidosis was also supported by anergic tuberculin skin test, decreased diffusing capacity of the lungs, increased serum ACE, increased CD4/CD8 levels in bronchoalveolar lavage fluid, and non-caseating granulomatous inflammation in mucosal biopsy of lung.

Exclusion of TB is important since corticosteroids are mainstay treatment for sarcoidosis (2). It is suggested that corticosteroid therapy should not be initiated until there is microbiological confirmation of mycobacterium culture in cases of dilemma in diagnosis between TB and sarcoidosis (7). In our case, radiological pattern was consistent with stage 2 sarcoidosis. AFB stain of the bronchial lavage was negative. Corticosteroid treatment was not implemented until mycobacterium culture results were returned due to high prevalence of TB in our country. The patient was also diagnosed with TB based on positive Lowenstein-Jensen medium culture of bronchial lavage. She was treated with anti-TB drugs for 6 months. There was radiological improvement of parenchymal nodules but no change in lymph nodes or interstitial opacities 
after anti-TB treatment. Clinical and microbiological assessments were TB coexisting with sarcoidosis.

In conclusion, differential diagnosis of granulomatous inflammation is difficult for clinicians. It is suggested that even if findings point to one of these diseases, coexistence of sarcoidosis and TB should be kept in mind.

\section{CONFLICTS OF INTEREST}

None declared.

\section{AUTHOR CONTRIBUTIONS}

Concept - S.A.B., A.B., S.K., S.G.; Planning and Design S.A.B., A.B., S.K., S.G.; Supervision - S.A.B., A.B., S.K., S.G.; Funding -; Materials -; Data Collection and/or Processing - S.A.B., S.G., A.B.; Analysis and/or Interpretation - S.A.B., S.K., S.G.; Literature Review - G.A.K.; Writing - S.A.B.; Critical Review - S.A.B., S.G.

\section{YAZAR KATKILARI}

Fikir - S.A.B., A.B., S.K., S.G.; Tasarım ve Dizayn - S.A.B., A.B., S.K., S.G.; Denetleme - S.A.B., A.B., S.K., S.G.; Kaynaklar -; Malzemeler -; Veri Toplama ve/veya İşleme S.A.B., S.G., A.B.; Analiz ve/veya Yorum - S.A.B., S.K., S.G.; Literatür Taraması - G.A.K.; Yazıyı Yazan - S.A.B.; Eleştirel İnceleme - S.A.B., S.G.

\section{REFERENCES}

1. Mandal SK, Ghosh S, Mondal SS, Chatterjee S. Coexistence of pulmonary tuberculosis and sarcoidosis: a diagnostic dilemma. BMJ Case Rep 2014. [CrossRef]
2. Badar F, Azfar SF, Ahmad I, Yasmeen S, Kirmani S. Diagnostic difficulties in differentiating sarcoidosis from tuberculosis. Oman Med J 2011 ; 26:210-21. [CrossRef]

3. Shah JR, Hede J, Mathur RS. Diagnostic criteria of tuberculous sarcoidosis. Lung India 2009; 26:86-8. [CrossRef]

4. Wong CF, Yew WW, Wong PC, Lee J. A case of concomitant tuberculosis and sarcoidosis with mycobacterial DNA present in the sarcoid lesion. Chest 1998; 114:626- 9. [CrossRef]

5. Oluboyo PO, Awotedu AA, Banach L. Concomitant sarcoidosis in a patient with tuberculosis: first report of association in Africa. Cent Afr J Med 2005; 51 :123-5.

6. Gupta D, Agarwal R, Aggarwal AN, Jindal SK. Sarcoidosis and tuberculosis: the same disease with different manifestations or similar manifestations of different disorders. Curr Opin Pulm Med 2012; 18:506-16. [CrossRef]

7. Mise K, Goic-Barisic I, Puizina-Ivic N, Barisic I, Tonkic M, Peric I. A rare case of pulmonary tuberculosis with simultaneous pulmonary and skin sarcoidosis: a case report. Cases J 2010; 3:24. [CrossRef]

8. Mortaz E, Masjedi MR, Matroodi S, Abedini A, Kiani A, Soroush $D$, et al. Concomitant patterns of tuberculosis and sarcoidosis. Tanaffos 2013; 12:6-9.

9. Gupta D, Agarwal R, Aggarwal AN, Jindal SK. Molecular evidence for the role of mycobacteria in sarcoidosis: a meta-analysis. Eur Respir J 2007; 30:508-16. [CrossRef]

10. Jindal SK, Gupta D, Aggarwal AN. Sarcoidosis in developing countries. Curr Opin Pulm Med 2000; 6:448- 54. [CrossRef] 